\title{
Když je kurikulární reforma evidence-less ${ }^{1}$
}

\author{
Stanislav Štech \\ Univerzita Karlova, Pedagogická fakulta, Katedra psychologie
}

Redakci zasláno 8. 8. 2013 / upravená verze obdržena 15. 9. 2013 / k uveřejnění přijato

16. 9.2013

\begin{abstract}
Abstrakt: Cílem studie je analyzovat „příběh“ kurikulární reformy, jak byl (je) podáván oficiální školskou decizí i řadou představitelů pedagogického výzkumu, a konfrontovat ho s výsledky pedagogicko-psychologických výzkumů vyučování a učení. V první části dokazuje, že potíže s formalismem její implementace a obecně její odmítnutí většinou učitelů netkví ve špatné komunikaci cílů reformy a v nedostatečné odborné pomoci učitelům při její implementaci. V druhé části dokládá, že v pozadí reformy je starý pedagogický spor - opírající se o pedagogické a psychologické teorie učení - mezi důrazem na procesy myšlení a důrazem na učivo. V další části dokazuje, že symbolem a jádrem reformy je pojem kompetence, který je špatnou odpovědí na skutečný problém. Tato odpověd' není podložená psychologickým výzkumem, dokonce je s jeho výsledky v rozporu. $\mathrm{V}$ poslední části uvádí některé z nich; týkají se hlavně reformní preference řešení problémů, zejména blízkých životu, jako metody vyučování. Tato preference je v rozporu s poznatky o vztahu pracovní a dlouhodobé paměti a teorie kognitivní zátěže. Dále představuje výzkumy tzv. průřezových kompetencí ukazující na riziko ignorování vazby na konkrétní předmět poznání. A konečně kriticky nahlíží na (dlouhodobý) transfer jako kriterium efektivnosti učení. Hlavní příčinu selhání kurikulární reformy tedy na závěr vidí ve výzkumy nepodložených východiscích (a tedy v jejím ideologickém zadání), v ignorování výsledků psychologických a didaktických výzkumů učení a také hlasů zahraničních výzkumníků, kteří v průběhu předešlé dekády kritizovali logiku a klíčové koncepty (rámce, kompetence) univerzálně prosazovaného typu kurikulární reformy.
\end{abstract}

Klíčová slova: kurikulum, reforma, kompetence, učení, transfer

Každé pojetí kurikula se musí dříve či později vyrovnat s otázkou svého zdůvodnění. Vyučování totiž představuje úsilí lidí i náklady různého druhu. Proto je třeba, aby to, co vyučujeme, mělo cenu (v obojím významu tohoto slova: aby to stálo za námahu i mělo nějakou směnitelnou hodnotu). Co si

1 Text volně navazuje na plenární referát Koncepce vzdělávání a kurikulární reforma, který byl autorem přednesen 21. března 2013 na 20. výroční konferenci České pedagogické společnosti na Fakultě př́rodovědně-humanitní a pedagogické Technické univerzity v Liberci. 
tedy zaslouží, aby bylo vyučováno, co je tak zásadní či fundamentální, že musí být předáno všem členům společnosti? Proč dát přednost jedněm poznatkům a dovednostem před jinými? A jak vybrané poznatky či dovednosti vyučovat? Jak potom hodnotit výsledky vyučování/učení a jeho efekty? To jsou základní otázky, které si neklademe jen v souvislosti s kurikulem, ale se vzděláváním vůbec.

Existují dva druhy důvodů, proč prosazovat konkrétní pojetí kurikula konjunkturální a zásadní.

Konjunkturální důvody mohou být zcela pragmatické (zlepšit naše postavení ve srovnávacích šetřeních PISA), dílčí (zlepšit vztah našich žáků k matematice) nebo podřízeny účelům ideologickým nebo ekonomickým (při zlepšení výsledků v PISA o jednu směrodatnou odchylku dosáhneme za 40 let dvojnásobného HDP; zaměstnavatelé požadují určitý profil znalostí a dovedností absolventa).

Zásadní, principiální zdůvodnění kurikula nemůže přednostně řešit otázku, co si žádá pragmatický zřetel každodenního života. Stojí na otázce hodnot. Hodnot, na kterých se společenost shodne jako na hodnotách zásadních, formativních. Tak např. konjunkturálními důvody lze zdůvodnit i to, že žáky nutíme, aby se naučili nazpamět' telefonní čísla všech nemocnic v telefonním seznamu. Neobhájíme to však principiálně (hodnotově): to, co vyučujeme, musí mít smysl především z hlediska utváření a rozvoje mysli (intelektu), senzibility, morálky atd. Vyučování je tedy neoddělitelně spjato s hodnotou vlastní vyučované věci. Poznatky a dovednosti, které předáváme, musejí mít tyto hodnoty samy v sobě. Jak jinak vysvětlit, proč vyučovat Shakespearovy sonety nebo kvadratické rovnice, když z pragmatického hlediska nemají pro konkrétního žáka evidentně žádný praktický užitek. Jen tehdy mluvíme o všeobecném vzdělávání (ve smyslu „fundamentálním, principiálním“). Angličtina to dobře ví, když rozlišuje education (blížící se německému Bildung) od pragmatického training (výcvik). Vzdělávání je tedy rozhodujícím způsobem postaveno na učivu a na jeho spojení s nějakým pojetím hodnoty (hodnoty pravdy, estetické hodnoty, morální hodnoty nebo hodnoty seberealizace atd.). Zasáhnout do kurikula, zejména jde-li o zásah radikální, pak musí stát na opravdu silném zdůvodnění. Jde totiž o změnu kulturní. Ta předpokládá hlubokou analýzu, teoretickou i empirickou, a debatu o důsledcích takové změny. 


\section{$1 \quad$ Jak interpretovat selhání kurikulární reformy?}

V posledních třech dekádách přitom veřejné mínění o funkci školního (i základního) vzdělávání ovládla neoliberální narace, tj. soubor vyprávění, které konkrétní změny ve vzdělávání vykládají jako samozřejmou, přirozenou a nevyhnutelnou reakci na „požadavky současné měnící se společnosti“ (Parlement européen, 2006; OECD, 2001; Rychen \& Salganik, 2001 ad.). Argumentují obvykle těmito důvody: žijeme ve společnosti, jejíž ekonomika je založena na vědění a službách, vyžaduje flexibilního, tvořivého a inovativního jedince, který se nebude spoléhat na stabilní kvalifikaci, ale bude sám podnikat a řešit komplexní problémové situace. Navíc jsme svědky exploze snadno dostupných informací, která stále více vyžaduje schopnost je kriticky zpracovávat a orientovat se v nich - spíše než fakticky je znát („najdeme si je na internetu“). A konečně, globalizace mj. zostřila neustálé srovnávání a soutěžení i na celoplanetární úrovni, takže každý musí být připraven (vzdělán) lépe než druzí, chce-li se uplatnit.

Proto je nezbytné provést reformu kurikula, která opustí dosavadní disciplinární soubory učiva, resp. dá je do služeb tzv. kompetencí. Tradiční učivo je prý tvořeno izolovanými faktografickými poznatky, je abstraktní a odtržené od života, žáky demotivuje a údajně nevede $\mathrm{k}$ dovednostem uplatnitelným $\mathrm{v}$ dalším životě. Česká kurikulární reforma byla v podstatě „copy-paste“ aplikací doporučení přicházejících ze Světové banky, OECD, Evropské komise, zaměstnavatelských svazů a dalších „rizomů“ (tj. oddénků, kořínků a větví) neoliberálního způsobu vlády. ${ }^{2}$

Podoba Rámcových vzdělávacích programů (RVP) byla vícekrát popsána; sám jsem se již kriticky vyjádřil ke klíčové změně v kurikulární reformě, tj. k podřízení učiva kompetencím v RVP (Štech, 2009). Školní praxe a většina učitelů podle (mého) očekávání reformu nepřijala (Straková, 2010); ta způsobila jejich roztrpčení a jistý zmatek. Jde nyní o to, jak budeme tuto situaci interpretovat. Zastánci představy o nezbytnosti zásadní reformy zaostávající české („tereziánské“ či „stále ještě tradiční”) školy vykládají celý příběh následovně. Žádoucí změny, které jsou vlastně „přirozené“, protože reagují na potřeby měnící se společnosti (povahu těchto změn nezpochybňují a přijímají je jako danost), musíme učitelům lépe vysvětlit. Selhala tedy komuni-

Metaforu „rizomu“ filozofů Deleuze a Guattariho rozvíjejí Kaščák s Pupalou ve své vynikající analýze neoliberální guvernmentality (Foucaultův pojem) ve vzdělávání a vzdělávací politice (Kaščák \& Pupala, 2012). 
kace smyslu a cílů reformy. Ve fázi implementace nebyli učitelé za práci navíc, kterou představovalo vypracování ŠVP, finančně motivováni a nedostalo se jim patřičné odborné podpory (Straková, v tomto čísle). ${ }^{3}$

Domnívám se, že interpretace, která říká, že „jádro je zdravé, logika reformy správná, jen je špatně implementována", neobstojí. V této stati se pokusím ukázat, že (1) základní logika a koncepty reformy kurikula nepředstavují nějaký objev či novinku, kterou reagujeme na zcela novou situaci (Crahay, 2006). (2) Klíčovým prvkem reformy je orientace na kompetence. Jejich vědecký status je však zpochybňován (Crahay, 2006; Rey, 2010) a jejich využitelnost ve školním vzdělávání omezená - a proto představují „pedagogickou mystifikaci“ (Hirtt, 2009). (3) Výzkumy pedagogické a kognitivní psychologie učení navíc zpochybňují také další pilíře kurikulární reformy, tj. dominantní orientaci vyučování na vyšší formy poznávací práce, jako je řešení problémů (srov. Schneider-Gilot, 2006), na průřezové kompetence a učení s transferem (Rey, 1996) a na úlohy (problémy) blízké každodenní životní zkušenosti žáků (srov. studii Rendl \& Štech, 2012).

\section{Nový problém nebo starý spor?}

Neoliberální diskurs přináší na první pohled nové důrazy: kritériem kvality i základního vzdělávání mají být „výstupy z učení", uplatnitelnost vědomostí v praxi, akontabilita, tj. srozumitelnost vykázaných výsledků vzdělávání každému (např. v podobě externí evaluace jejich užitečného využití v praktických životních problémových úlohách) - to vše symbolicky koncentrované

3 Poslední tvrzení není podle mého soudu úplně pravdivé. V letech 2004-2006 byla uskutečněna celá řada výjezdů odpovědných pracovníků MŠMT do terénu, na nichž byla vysvětlována podstata reformy. Dále bylo realizováno několik projektů ESF jako např. Koordinátor nebo prostřednictvím NIDV projekty DUM pro školy (Projekt Peníze školám). Nešlo jen o vysvětlování, ale o finančně i odborně podpořenou přípravu ŠVP. Připraveno bylo několik podpůrných metodických portálů (např. www.rvp.cz, www.rvp.cz/gympliste, www.pilot-gp.cz ad.) a množství příruček a textů, zejména pod gescí VUP, NUOV a NIDV (viz např. Školská reforma pokračuje. Vzdělávání v r. 2008 v tématech, MŠMT 2008). Problém vidím někde jinde - příkladem může být posun pojetí u projektu Koordinátor. Původní představa počítala s těmi nejzkušenějšími metodiky ze škol, kteří by byli schopni kvalifikovaně posoudit možnosti a hranice experimentování s učivem např́íc předměty. Místo toho se stal př́ležitostí pro byrokratické instrukce úředníků z MŠMT, resp. NIDV. Je však také pravděpodobné, že zkušení metodici ze škol by rozporovali základní principy, resp. pojetí reformy. Jedním z negativních výsledků reformy je třeba zánik certifikačního procesu u celostátních učebnic. Idea, že učitelé si učební materiály při tvorbě ŠVP budou vyrábět sami, je zcela v logice této podoby kurikulární reformy a dokládá podřízení učiva kompetencím. 
především do pojmu „kompetence“. Pojem je to ještě v 90. letech v pedagogickém prostředí dostatečně neznámý a nejasný, a tak může úspěšně navozovat dojem řešení nové situace. Budu se mu proto podrobněji věnovat $\mathrm{v}$ další části.

Ve skutečnosti se však za novým diskursem skrývají stará témata: vyučování/ učení ve škole by nemělo spočívat v memorování mrtvých poznatků; mělo by vycházet z toho, co si dítě spojí se svou životní zkušeností a co později ve svém životě uplatní, zejména na trhu práce. Při bližším ohledání tedy zjistíme, že jde o starý spor v novém kabátu. Jeho jádrem je míra diskontinuity mezi školní a mimoškolní kulturou. Především je třeba říci, že všemi reformními návrhy na změnu školního vzdělávání v posledních 130 letech se jako červená nit táhne snaha překlenout údajný hiát mezi školním a mimoškolním světem. Z odsuzování a kritiky školy za to, že svět a život školy není školou života, se již stalo klišé. Nejprve bylo součástí diskurzu nové výchovy či reformní pedagogiky. V posledních dvaceti letech se stalo leitmotivem, implicitním východiskem, které ani není třeba dokládat, i současných reforem školního vzdělávání.

Crahay (2006) připomíná, že již v Deweyho práci The child and the curriculum. Contributions to education z r. 1902 je nastolena opozice mezi implicitním, spontánním učením (situation-centered curriculum) a explicitním, formálním učením (subject-centered curriculum). První orientace říká, že žáka je třeba konfrontovat s autentickými životními situacemi, aby si poznatky osvojil vlastní zkušeností; má se učit realitou. Dewey také kritizuje tradiční oborový přístup ztvárněný ve vzdělávacích předmětech: je třeba přejít od učiva strukturovaného ve vzdělávacích předmětech k životním problémovým situacím, v nichž učivo ztrácí svůj charakter učiva. Mezi známými autory najdeme řadu stoupenců tohoto přístupu ke kurikulu - Rousseaua, Claparèda, Decrolyho.

Naproti tomu kurikulum, které je zaměřeno na předmět, se opírá o vědní nebo umělecký obor a jeho kánony. Takové pojetí kurikula vychází z potřeby uvést dítě do kultury, která je výsledkem vývoje lidstva, jež své dosavadní poznání v těchto oborech kodifikovalo. A žákům je třeba poskytnout dostatek př́ležitostí, aby si mohli tyto kódy vědomě za pomoci zkušených pedagogů osvojit. Tato tendence se odvolává nejen na Herbarta, ale díky důrazu na kulturní kódy také na Vygotského nebo Brunera. 
Tomuto sporu či napětí tradičně odpovídalo napětí mezi důrazem na metody učení vs. na jeho předmět. $V$ jiném vyjádření šlo o napětí mezi důrazem na obecné, na vyučovaném předmětu zdánlivě nezávislé a v tomto smyslu „průřezové" poznávací činnosti žáka vs. na specifické znaky předmětu, kterému se tato činnost věnuje. Ve většině zemí je také běžné napětí mezi oborovými didaktiky obvykle citlivými na to, co se děje s oborovými poznatky a s učivem, a pedagogy a psychology citlivějšími na to, co žáci s těmito poznatky skutečně dělají.

V 60. letech minulého století se uvedený spor objevil znovu díky nové britské sociologii kurikula (B. Bernstein, M. Young, P. W. Musgrove). Nabyl podobu dvou modelů kurikula charakterizovaných tzv. seriálním vs. integrovaným kódem. Britští sociologové již před více než 40 lety ukazují nejen na rizika výrazné preference integrovaného kódu stavějícího na projektové výuce přibližující školu životu a rušící hranice mezi obory/vyučovacími předměty (srov. např. Štech, 2009). Především upozorňují, že každé učivo je sociální konstrukcí a výsledkem často konfliktních bojů mezi oborovými či profesními skupinami, které se snaží rozšśřit hranice svého vlivu. Neexistuje tedy žádná „objektivní potřeba“ či „požadavek společnosti“, kterému je žádoucí školní vzdělávání přizpůsobit.

V průběhu minulého století tomuto napětí odpovídala opozice „konzervativci“ (stojící na straně tradičního oborového učiva) vs. „progresivisté“ (prosazující výuku prostřednictvím praktické zkušenosti blízké životu žáků); velmi zhruba tomu odpovídaly tábory pravicové a levicové školské politiky. Dnes však jedni (Deer, 2006; Goodson, 2008; Young, 2007) zdůrazňují, že výrazná relativizace oborového učiva a přehnaná banalizace školní formy vzdělávání zvyšují vzdělávací nerovnosti a nespravedlivost. A kromě toho nenesou očekávané výsledky. Kritika školní formy vzdělávání a abstraktního a od života odtrženého učiva přitom v minulosti charakterizovala spíše stoupence levicových přístupů „přiblížení školy životu dětí z lidových vrstev“. Levicová školská politika však dnes bojuje spíše za právo na „skutečné zlepšení“ (enhancement right) pro všechny důrazem na osvojení kánonů příslušných oborů (B. Bernstein).

Na druhou stranu jiní (např. Lannoye et al., 19994) ve jménu efektivní a jedinci užitečné školy hlásají přístupy zaměřené hlavně na poznatky a kompeten-

4 Podle nich „učitelé musejí utlumit své přání, aby poznatky měly řád a pevnou organizaci, a rezignovat na vzorové výklady bez překvapení". 
ce potřebné $\mathrm{v}$ budoucím občanském a pracovním životě žáka spíše než na oborové poznatky a vědomosti. Tradičně tento přístup charakterizoval spíše levicovou školskou politiku a dnes se zdá, že jeho hlasateli jsou především představitelé neoliberální agendy. V ČR je dominantně slyšet tento hlas - první skupina jako by ve veřejném prostoru zcela chyběla. ${ }^{5}$

Young (2007) hledá řešení uvedené tenze v diferencovaném přístupu k učivu. $\mathrm{V}$ tradičním oborovém učivu rozlišuje tzv. potencující poznatky (powerful knowledge) nezbytné pro pochopení světa i společenskou úspěšnost. Říká, že jde především o ty poznatky $\mathrm{v}$ učivu, se kterými se děti ze sociálně znevýhodněných rodin nemohou setkat nikde jinde než ve škole. Odmítá přitom, že by tím hlásal návrat $\mathrm{k}$ tradiční školní výchově elit. Požaduje model, který nebude ani prostým návratem k tradičně elitářskému a sociálně „nerovnému“ vzdělávání, ani tržně mimetickou neoliberální školou: „If the curriculum is too driven by content (as in the old elitist model), or skills and competence (as in the new generic model) some important educational goals (such as opportunities for progression) will get lost" (Young, 2010, s. 10).

Cílem školního vzdělávání podle něj musí být v co největší možné míře zajistit, aby si každý mohl osvojit poznatky, které ho vyvedou za hranice jeho osobní zkušenosti; poznatky, které by si nemohl nikdy osvojit doma, ve svém volném čase, v pracovní činnosti. Má-li vzdělávání tuto funkci splnit, musíme uznat nezbytně školní charakter pojmů a procesů učení, které nemohou být generické a oddělené od svých oborových (disciplínových) kořenů. Přitom však nesmíme přejmout tradičně elitářský přístup ke kurikulu, který implicitně počítá s kognitivními i sociálně-afektivními předpoklady žáka z vyšší střední třídy u všech žáků. Zamlčeným důsledkem této analýzy pak je skutečnost, že vnitřní koherence poznatků, principy jejich soudržnosti a postupy, jak se vytvářejí poznatky nové, jsou v jednotlivých oborech odlišné - a tuto odlišnost nelze redukovat či převést na "společný jmenovatel“ bez ztráty podstaty příslušného poznatku. Young, Goodson nebo Deerová se tak jednoznačně stavějí proti myšlence generických kompetencí jako vzoru pro vybudování kurikula.

Výjimkou by na první pohled měli být stoupenci vzdělávací inkluze. Dosud však v jejich požadavcích zcela absentuje didaktická a epistemologická analýza učiva a omezují se tak bud' na vnější materiálně-organizační podmínky inkluze, nebo se spokojují s prưřezovými tématy a kompetencemi jako kritériem a garantem úspěšnosti vzdělávání. 


\section{Kompetence - pedagogická mystifikace aneb špatná odpověd' na skutečný problém}

Od 80. let nejprve v USA, později i v Evropě (u nás zhruba v polovině uplynulé dekády) se také pod tlakem neoliberálních ekonomů a podnikatelských kruhů objevují dokumenty, které kritizují školní vzdělávání založené na oborovém kódu a prosazují př́klon ke kompetencím jako cíli vyučování/učení. Zdrojem, někdy až modelem formování kompetencí se pochopitelně stává odborná př́íprava a jejím prostřednictvím způsob myšlení a jednání v průmyslovém podniku. Např. dokument European Round Table již v r. 1989 tvrdí, že „průmysl má na učivo př́liš malý vliv“ (s. 1), a proto je vzdělávání neefektivní. Bílá kniha Růst, konkurenceschopnost a zaměstnanost - výzvy a cesty vpred do 21. století (1993), podobně jako Bílá kniha Vyučovat a naučit: na cestě ke kognitivní společnosti (European Commission, 1995) upozorňují, že „,kompetence tvoří sokl, na kterém se tvoří individuální schopnost zaměstnatelnosti“ (s. 15).

Kanad'ané Boutin a Julien (2000) však vnímají zavedení vzdělávacího přístupu zaměřeného na kompetence jako „manipulaci vzděláváním, která ho podřizuje ideologii ekonomické výkonnosti a účinnosti na úkor kultury a rozvoje jedince, nebo dokonce na úkor učení samotného". Pokračují tím, že tato „reduktivní vize“ vzdělávání představuje jakýsi „dlouhý nos“ na většinu učitelů i jejich vzdělavatelů.

Pojem kompetence tedy vzniká ze souběhu očekávání světa podnikání a některých pedagogických koncepcí, které jsem zmínil v předchozí kapitole. $\mathrm{V}$ prvním př́ípadě jde o to disponovat adekvátně vyškolenou (tj. dokonale na všechny situace připravenou) a pružně využitelnou pracovní silou a současně minimalizovat vlastní náklady na její nutný výcvik v praxi. Ve druhém př́ípadě jde o pedagogická hnutí a koncepce orientující se na individuální projektovou výuku, aktivizující konstruktivistické proudy apod. Společně pak vítají nový slovník: na výsledcích (výstupech) založené vzdělávání, standardy, benchmarky atd.

Hirtt (2009, s. 4-5) shrnuje, že za orientací vzdělávání na kompetence se skrývají hlavně ekonomické cíle - posloužit trhu práce. I přes chlácholivé řeči zastáncủ tohoto přístupu vede k zanedbání práce s učivem, nevede k aktivizaci žáků v učení a místo stimulace pedagogické inovativnosti zavádí učitelskou praxi do byrokratické rutiny. Navíc se po letech ukazuje, že představuje prvek silné deregulace posilující sociální nerovnosti. 
Pojem kompetence je jednoznačně nejfrekventovanějším pedagogickým pojmem posledních patnácti let. $\mathrm{V}$ souvislosti s frekvenční obsahovou analýzou tohoto pojmu upozorňuje Hirtt (2009), že výrazy jako „obsese kompetencemi“ Boutina a Juliena nebo „nové jednotné pedagogické myšlení Tilmanta (2005) jsou empiricky podložené a jednoznačně ukazují, že tento pojem je výrazně spojen až s érou globalizace (Hirtt, 2009, s. 1 a 5).

$Z$ většiny studií zabývajících se kompetencemi (Bosman, Gérard, \& Roegiers, 2000; Crahay, 2006; Rey, Carette, \& Kahn, 2002) se můžeme pokusit o jakousi souhrnnou definici: jde o schopnost jednat, jejímiž stavebními kameny jsou vědomosti a dovednosti, avšak tato schopnost se na ně nedá redukovat. Kompetence je tvořena i dalšími prvky (např. spontánně získaný habitus nebo kulturní zkušenost), které je třeba umět mobilizovat, a to v situacích, které jsou nové (ve škole se nenacvičovaly) a nejčastěji mají charakter řešení problémů podobných běžnému životu. Tuto schopnost jednat vykazují především zkušení jedinci (experti). Věnujme se tedy hlavním prvkům tohoto vymezení kompetence.

Za prvé, schopnost jednat jako ideální vzdělávací cíl vychází z představy flexibilního pracovníka schopného inovativních řešení pracovních situací. Nejde jen o schopnost aplikovat naučený algoritmus, jako tomu bylo dř́ve, ale o schopnost „nějak si poradit“. To je prý důsledkem změny povahy práce práce ve znalostní společnosti se od industriální liší právě sníženou mírou rutiny. Efekt tohoto akcentu je dvojí: jednak je osvojení takové schopnosti spíše záležitost jedince a jeho osobní odpovědnosti, protože jde o schopnosti formované v situacích, které se ve škole nevyučují; jednak se současně s důrazem na kompetence ř́ká, že to, co se vyučuje ve škole, je nedostatečné, neúplné, protože v praxi málo využitelné. Kompetence tak představují jakousi „konativní slitinu“, kterou nelze jednoznačně vztáhnout k žádné specifické psychologické nebo pedagogické koncepci či teorii. ${ }^{6}$ Každá solidní př́íprava vzdělavatelů učitelů přitom musí vycházet z konzistentních teoretických východisek. Těžko tedy učitele vzdělávat a připravovat na vyučování zaměřené na kompetence.

6 Podle Crahaye je to „Ali Babova konceptuální jeskyně“ - stoupenci kompetencí používají i obvykle si protiřečící teoretické konstrukty piagetovského konstruktivismu (s pojmy schématu či invariantu, jak na nich staví obhajobu kompetencí Perrenoud, 1997), kognitivní psychologie (s pojmy deklarativní a procedurální poznatky, poznatky strategické nebo metakognitivní, jak je v kompetencích nachází např. Tardif, 1999) nebo teorie situovaného učení (s pojmem každodenní poznávání a situačně kontextové vědění, jak se objevuje např. u Rogoffové nebo Laveové a Wengera). Za krajně paradoxní pak lze podle Crahaye (2006, s. 101) považovat snahu vytvořit jednoduše pojem (kompetence), který všechny tyto různorodé teoretické konstrukty sjednotí. Jde podle něj o simplifikující iluzi. 
Za druhé, jádrem kompetence se zjevně stává moment mobilizace. Lze např. říci, že to, co měří testy a položky typu PISA, nejsou vědomosti a dovednosti, ale schopnost mobilizovat, co jedinec ví (a naučil se nejen ve škole), umí udělat, prožil jako svou kulturní zkušenost ve škole i mimo školu. Je ovšem pravda, že schopnost mobilizace představuje skutečný problém, velkou a málo zkoumanou výzkumnou otázku. Jak probíhá mobilizace různých kognitivních a afektivních „zdrojů“ v různých situacích? Za jakých podmínek a které z nich se dají navodit ve škole? Takové otázky však s nástupem ideologie kompetencí nebyly kladeny. Vzniká také otázka, zda a do jaké míry lze získat schopnost mobilizace zdrojů bez faktických vědomostí a bez porozumění oněm situacím (předpokládajících nutnou obeznámenost s nimi - kterou děti v některých kulturách či zemích mají, v jiných nikoli). Mobilizace je vždy nutně jen výběrem malé části toho, co subjekt ví a umí - toho, co se bezprostředně hodí $\mathrm{k}$ vyřešení dané komplexní situace. Proto by zaměřením na výcvik kompetencí vzniklo silné riziko svévole a redukce kurikula, ř́ká Hirtt (2009, s. 17). Kdo z nás kdy mobilizoval k řešení nějaké životní situace básně Jana Nerudy, integrály, principy impresionismu, průběh tektoniky zemských desek nebo Descartesovu filozofii? Proto se dnes v duchu tohoto pedagogického naivismu navrhuje učit se komunikovat, aniž bychom se obtěžovali gramatickými pravidly; učit se číst kriticky historický dokument, aniž bychom žáka přetěžovali detailní historiografickou faktografií; nebo se ještě spíše preferuje vypracování projektu, jak upoutat turisty krásami gotického kostela. Kompetence jako umění mobilizovat nějaké jednání či postup nezávisle na obsahu nebo předmětu vrací podle Hirtta do hry představu o jakémsi speciálním potenciálu řešit třeba matematické problémy nezávisle na povaze a míře osvojení konkrétních matematických operací. Různá úroveň kompetencí a jejich nejasná geneze i podmínky mobilizace pak podle něj nevylučují možnost, že se v budoucnu vrátí s obnovenou silou stará ideologie geneticky podmíněných „vloh“ („mít buňky na“).

Poslední charakteristikou kompetence, kterou zde zmíním, je mimořádný důraz na novost a jedinečnost situací, $v$ nichž se úroveň kompetence diagnostikuje. Nemohou to být situace dítěti jakkoli známé nebo viditelně připomínající to, co se učilo ve škole. ${ }^{7}$ Kdyby se alespoň na něco $\mathrm{z}$ této situace ve škole připravilo, nepůjde už o kompetenci, ale o dovednost, algoritmus, aplikaci známého. A vytratí se tajemný nádech tvořivosti a objevu. Crahay

7 Je zjevné, že se zde nereflektovaně vynořuje tradiční pojem psychologie učení - transfer. Vybraným výzkumům a pojmům, které jsou v kurikulární reformě ignorovány, se budu věnovat v poslední části této stati. 
pak ve svém kritickém textu vyjadřuje dvojí údiv. Na základě čeho, ptá se, lze rozumně požadovat, aby se vyučování ve škole přednostně zaměřilo na situace a dovednosti, které nemají být vyučovány. Tedy jak lze ze schopnosti zvládat neočekávané a neznámé učinit vědomý vzdělávací program? A druhá otázka zní: jaký má smysl připravovat žáka na něco, co s vysokou pravděpodobností nastane $\mathrm{v}$ jeho životě výjimečně? Zatímco drtivá většina jejich praktického života bude stát na dokonalém osvojení rutiny a algoritmů. Žáky nelze vzdělávat jako krizové manažery, říká Crahay (2006, s. 102). Jakmile hodnocení úrovně kompetence vyžaduje neznámé situace s novou strukturou komplexity, měříme něco, co nemá prokazatelnou přímou souvislost s vyučováním/učením ve škole. A právě to se má v kurikulárních reformách stát normou školního kurikula.

Přesto je třeba říci, že obrat ke kompetencím upozornil na reálné problémy školního vzdělávání. Již jsme zmínili, že málo známe způsob, jakým nováčci kultury mobilizují své kognitivní zdroje, a proč jsou v některých situacích úspěšní a jindy selhávají. Dalším skutečným problémem je to, co didaktik Martinand (2003) nazývá „věčná tendence školy k autoreferenci“. Jde o známou tendenci pouze opakovat kánony vědních postupů i ve vyučovacích předmětech a ignorovat „referenční sociální praktiky“, tj. způsoby, kterými tyto poznatky kdysi vznikly a jak se užívají mimo školu nyní. I kritici obratu ke kompetencím kritizují tendenci školy „naturalizovat“ oborovou, vědní formu poznatků a podceňovat jejich sociokulturní a situační „zrod“ (Harlé, 2010). Poznatky tak zůstávají pro žáky „mrtvé“. Kurikulum kompetencí je pak špatnou odpovědí na tyto existující problémy.

Modelové představě, že efektivní učení nastává především při řešení problémů, jak ho demonstrují experti, se budeme věnovat v poslední části textu. Sledujeme-li pozorně výsledky pedagogicko-psychologického výzkumu učení, jeho historii i současné polemiky, udiví nás především míra jejich ignorování konceptory kurikulární reformy.

\section{$4 \quad$ Paradoxy evidence-based éry: ignorování výsledků výzkumu}

Nejen u nás při zavádění kurikulární reformy absentovaly argumenty pedagogicko-psychologického výzkumu (různá expertní šetření na politickou objednávku nelze považovat za nezávislý výzkum). Domnívám se, že i to přispělo k neúspěchu kurikulární reformy. Proto se chci na závěr zmínit jen 
o dvou tématech výzkumu učení, jehož výsledky mohly při objektivnějším zkoumání varovat před ideologickou aplikací reformy. Je to téma řešení problémů (zejména problémů blízkých životu, real-world problems - RWP) jako nejpřínosnější a nejefektivnější podoby vyučování/učení s přáním učinit z něj obecnou strategii vzdělávání. A dále o téma průrezových kompetencí $\mathrm{s}$ implicitním předpokladem úspěšného transferu jako výsostného kritéria kvality učení.

Pokud jde o předpoklad, že zaměření vyučování na vyšší kognitivní formy učení, jako je řešení problémů, představuje nejefektivnější metodu vyučování, většina výzkumů již od Thorndika to vyvrací. Thorndike ve své Psychologii aritmetiky (1922) poprvé ukázal, že efektivní učení předpokládá dril a automatizaci, vysvětlení obecného principu a následné procvičení. V experimentální podmínce, $v$ níž žáci sami hledali obecný princip řešením problémové slovní úlohy bez dostatečně zautomatizovaných aplikací „principu“, sice také dospěli k úspěšnému řešení. Kognitivní zátěž, kterou na to vynaložili, však znemožnila tento poznatek uložit do dlouhodobé paměti a využít ho později při řešení problému s mírně jiným zadáním (opakovaně to bylo později potvrzeno výzkumy tzv. cognitive load theory - teorie kognitivní zátěže, které uskutečnil Sweller a jeho spolupracovníci, např. 1983, 1994).

Jiné výzkumy zase ukázaly, že úspěšné řešení problémů závisí významně na kvalitě struktur konkrétních oborových vědomostí. To je v rozporu s názory příznivců obratu ke kompetencím, kteří kladou velký důraz na osvojení na obsahu nezávislých technik řešení problémů. ${ }^{8}$ Již Minsky (1974), po nich Glaser (1984) a Sternberg (1985) nebo Fayol (1991) opouštějí jednostranný důraz na obecnou schopnost reflexe ve prospěch důrazu na strukturu dostatečně dobře osvojených vědomostí, ze kterých se vynořuje nebo vyrůstá schopnost řešit komplexnější kognitivní úlohy. Minsky (1974) pracuje s pojmem bazální vědomosti a ukazuje, že při práci se začátečníky se učitelé mají zaměřit na upevnění, až automatizaci těchto bazálních vědomostí, protože pokroky žáků směrem $\mathrm{k}$ řešení komplexnějších úloh jsou výsledkem kvalitního vyjadřování, rozpoznávání a užívání konkrétních poznatků: „není totiž vůbec zřejmé, že inteligentní lidé se vyznačují především vyšší kvalitou nějaké obecné metody myšlení (reasoning). Kvalita jejich inteligence spíš spočívá v hlubší znalosti organizace či uspořádání poznatkư" (Glaser, 1984, s. 264).

8 Protože u řešení problémů předpokládají jako jeho výsledek významný transfer - a jak uvidíme v dalším textu - neoprávněně. 
Ve čtení textu s porozuměním doložili poměrně přesvědčivě Recht a Leslie (1988), že konkrétní, dobře upevněné vědomosti hrají klíčovou roli v procesu porozumění textového sdělení. Vytvořili skupinu stejně starých a jinak stejně školsky úspěšných dobrých a špatných čtenářù. Všem žákům dali test na znalosti z baseballu, aby v obou skupinách identifikovali ty, kteří tento sport dobře znají, a ty, kteří o něm skoro nic nevědí. Pak požádali každého ze žáků, aby si přečetl text o 625 slovech, který pojednával o baseballovém utkání.

Porozumění textu bylo vyhodnoceno trojím způsobem: nejprve měli žáci pomocí figurín reprodukovat, co četli, a komentovat hlavní fáze utkání; pak měli text shrnout; a nakonec vybrat a zopakovat 22 nejdůležitějších vět textu. Výsledky pokusu jasně ukazují, že k úspěchu v popsaných úkolech je lepší být špatný čtenář, ale znát dobře baseball, než být výborný čtenář, který o dané hře neví vůbec nic. Dokazují tím, že kritický rozdíl spočívá v rozdílné základně konkrétních informací, nikoli v obecných intelektuálních dovednostech typu gramotnosti, tj. umět číst text a rozumět mu. Navíc můžeme konstatovat, že úspěch při řešení problémové otázky „blízké životu“ významně závisí nikoli na schopnosti kriticky a s vhledem číst text, ale spíše na kulturní zkušenosti žáků. ${ }^{9}$

Chi, Feltovich a Glaser (1981) provedli řadu výzkumů s cílem zjistit, jak řeší problémy ve svém oboru poznání (šlo o mechaniku a radiologii) experti - a jak se jejich expertskost rodí a rozvíjí - ve srovnání s tím, jak stejné problémy řeší začátečníci. Empirická výzkumná data ukázala, že vědomosti nováčků se organizují či strukturují kolem konkrétních předmětů explicitně zmiňovaných v zadání problémové úlohy. Naproti tomu experti strukturují své poznatky $\mathrm{v}$ problémové úloze kolem principů a abstraktních schémat stojících za konkrétními předmětnými údaji tvořícími problémovou úlohu. Tyto principy či schémata jsou sice skryté, ale experti je aktivují na základě své důkladné znalosti oboru, podobně jako žáci-experti identifikující klíčové sdělení textu o baseballovém utkání. Autoři uzavírají, že potíže začátečníků (a těmi jsou žáci vždy znovu v každé nové oblasti učiva) při řešení problémů lze nejspíše přičítat nedostatečné základně znalostí a nikoli nedostatečným intelektuálním kompetencím, jako je např. neschopnost využívat heuristické strategie apod. (viz též Chi, Glaser, \& Farr, 1988).

9 Jde mimochodem o jednu ze základních kritik nerespektování tzv. kulturního biasu v šetřeních PISA, resp. v neuvážené interpretaci jeho výsledků jako dokladů o kvalitě školního vzdělávání (k tomu u nás srov. Kaščák \& Pupala, 2011). 
Kognitivisté kladoucí důraz na struktury uspořádání poznatků (curriculum taught), resp. vědomostí (learned knowledge) nás proto upozorňují, že kritickým momentem při řešení komplexnějších kognitivních úloh, jako je řešení problémů, je reprezentace problému, jeho mentální model. A že žák si utváŕí reprezentaci problému tak, že strukturuje jeho zadání v závislosti na svých dosavadních znalostech. Ty musejí být aktivovatelné v podstatě automaticky, vyvoláním z dlouhodobé paměti. Klasický příklad uvádějí Resnicková a Fordová (1981):

$\mathrm{V}$ první etapě řešení jakéhokoli problému se musí vytvořit jeho reprezentace, tj. vzít v úvahu jeho specifika a zakódovat je tak, aby byly interpretovatelné naším dosavadním systémem zpracování informací. Jinak řečeno, informace obsažená ve formulaci problému musí být zakódována ve formě slučitelné se strukturou dosavadních vědomostí jedince. Což umožňuje využít dříve konstruované vědomosti při řešení nového problému. ( s. 214)

Na mnoha př́́kladech řešení slovních úloh v matematice ukazují, jak je pro úspěšnéřešeníproblémudůležitámobilizaceadekvátníhoaautomatizovaného matematického nástroje. Tedy jak je důležité, že žák vyvolává z dlouhodobé paměti stabilní, upevněné modely (např. $1 \mathrm{~m}=100 \mathrm{~cm}$; operace odčítání a přičítání, kdy 153 - 5 není v podstatě rozvinutě počítáno, ale výsledek 148 vypadne jakoby „rovnou“), což uvolňuje kapacitu pracovní paměti pro mentální inference a operace, jako je např. implikace typu jestliže ..., pak. To vše je ovšem závislé na správném dekódování problémové situace. Jinými slovy, řešení problémů se ve škole učíme - učíme se ale především správně dekódovat, tj rozpoznat, kterou z naučených vědomostních a operačních struktur přiřadit „temné" problémové situaci. Současně nám teorie kognitivní zátěže ř́́ká, že je nutné řešení problémů praktikovat v rozumné míře právě pro to, aby se poznatky objevené při řešení uložily do dlouhodobé paměti. Recentní výzkumy vztahu pracovní a dlouhodobé paměti dokazují, že myšlení (reasoning) je vlastně manipulováním reprezentací v pracovní paměti. Je-li její kapacita omezena, tj. přetížena neschopností použít zautomatizované modely operací a schémat jejich vyvoláním z dlouhodobé paměti, představuje to mnohem vážnější překážku pro kvalitu myšlení než př́lišná abstraktnost učiva (de Jong, 2010; Sweller, 1983, 1988, 1994, 2005). 
Poučení z výzkumů? Orientovat vyučování na řešení problémů (zejména blízkých životu, v nichž je „princip“ nebo vědomostní struktura implicitní, skrytá) je zejména u začátečníků riskantní záležitost. Navíc, nelze stavět do protikladu upevňování vědomostí a operací procvičováním a memorizací a vyšší formy myšlení přítomné v řešení problémů. ${ }^{10}$ Vzájemně se podmiňují a potřebují.

Pokud jde o průřezové kompetence a o transfer, výsledky výzkumů kognitivní psychologie jsou velmi skeptické. Schneider-Gilotová (2006) uvádí, že dlouhodobý transfer (far transfer) není potvrzen ani mezi různými činnostmi v rámci jednoho oboru/předmětu, ani mezi obory/předměty. Ve své studii vyčítá upřednostňování průřezových kompetencí především to, že dává důraz na prvky společné více oborům/předmětům a podporuje tak „mýtus transferu vedoucí k likvidaci povědomí o epistemologické zvláštnosti každého z nich; dále vede $\mathrm{k}$,dekategorizaci' otázek studovaných ve škole“ (s. 85). Své empirické výzkumy vedoucí ji ke kritice průřezových kompetencí uskutečnila v (školní) matematice, dějepisu a v př́rodních vědách. Každý předmět, kterým žák prochází ve školní docházce, vyžaduje specifické, odlišné postupy, nutí podř́ídit se odlišným omezením a normám a osvojit si jiné kódy reality, které nejsou redukovatelné jeden na druhý a jejichž „společný jmenovatel“ je nakonec jen prázdná formální skořápka typu „kriticky zvažuje, formuluje hypotézu, srozumitelně komunikuje výsledky" (Schneider-Gilot, 2006, s. 94).

Také Rey (1996) upozorňuje, že dovednost (kompetenci?) nelze nikdy oddělit od jejího konkrétního oborového obsahu: „umět vyřešit kvadratickou rovnici, to je kompetence. Umět řešit problémy - to není žádná kompetence, to je prázdná floskule ... nanejvýš může jít o spekulaci psychologů. Avšak současný stav empirických výzkumů nedovoluje takovou spekulativní konstrukci jakkoli potvrdit" (s. 87). Jakoby ozvěnou si vybavíme slavnou půl století starou sentenci J. Brunera „myšlení jako takové neexistuje, myšlení je vždy myšlením o něčem“.

Podobně Baillargeon (2006) považuje formování průřezové kompetence mimo kontext konkrétního vědního/uměleckého oboru, resp. vzdělávacího předmětu za málo funkční a na adresu příznivců kurikula kompetencí volí ironicky následující analogii: „hledají, jak rozvinout kreativitu jako takovou

10 Podrobně to dokládáme pro vyučování/učení matematiky v naší studii, srov. Rendl \& Štech (2012). 
nebo obecnou schopnost řešit problémy a podobně. Je to tak trochu, jako bychom po škole žádali, aby naučila žáky hrát - bez ohledu na to, zda půjde o hokej, karty nebo šachy“" (s. 165).

Rey (1996) hovoří přímo o iluzornosti průřezovosti: navrhuje nanejvýš užívat pojem průřezová intence, čímž chce říci, že „průřezovost“ je nejspíš něco v řádu záměru, přání nebo smyslu, kterou má situace učení pro jedince. Průřezová kompetence je podle něj přáním pedagoga, aby výsledky žáků překročily hranice školního vyučování/učení a měly trvalou stopu, byly jaksi transcendentní. V takovém př́ípadě však už nejde o problém kognitivní, ale afektivní.

Zdá se, že koncept transferu, tedy schopnosti přenášet známé poznatky a dovednosti do zcela nové situace ( $\mathrm{v}$ prŕṕpadě dlouhodobého transferu pak „do života“) jako by v sobě krystalizoval všechna zásadní očekávání, která společnost má vůči škole - a která jsou o to silnější v době tzv. krize školy, připomíná Schneider-Gilotová (2006). Podle Tardifa je transfer pověstným „kamenem mudrců“ školní pedagogiky a odvíjí se ze zakladatelského mýtu školy (1999).

Ukazuje se však, že ve většině studií mají různé postupy, které mají zvýšit transfer, vliv nanejvýš na blízký transfer, tj. efekt je zjištěn v kontextově blízkých oblastech a po relativně krátké době. Dlouhodobý transfer na úlohy s výrazně odlišnými kontexty nebo předměty je neprokazatelný.

Jinde jsme se $\mathrm{v}$ sekundární analýze zahraničních výzkumů podrobně věnovali otázce transferu ve vyučování/učení matematice. Doložili jsme, že je výzkumně obtížně uchopitelný nebo spíše neuchopitelný. Nedávné diskuse zahraničních autorů o potřebě nového pojetí transferu nás dovedly $\mathrm{k}$ pochybnostem o opodstatněnosti samotného pojmu. Jeho existence nakonec vytváří jen jakousi paralelní teorii učení, která je však zakotvena jen v odlišných verbálních pojmech a nikoli v reálných fenoménech, které by byly oddělitelné od fenoménů procesu učení (Rendl \& Štech, 2012).

\section{Závěr}

Zdá se, že již východiska kurikulární reformy, která postihla většinu zemí pod neoliberální guvernmentalitou, nebyla doložena seriózním pedagogickopsychologickým nebo didaktickým výzkumem nebo jsou s nimi v rozporu. Nechci říci, že její odmítnutí učiteli bylo u nás dáno právě touto skutečností. 
Nelze ale také podcenit intuitivní tacitní vědění učitelů o procesech učení žáků a vše svádět na jejich konzervatismus a neochotu měnit zaběhaný řád věcí.

\section{Literatura}

Gardner, D. P. et al. (1983). A nation at risk: The imperative for educational reform. Washington, DC: National Commission on Excellence in Education.

Baillargeon, N. (2006). La réforme québécoise de l'éducation: une faillite philosophique. Possibles, 30(1), 139-184.

Bílá kniha Růst, konkurenceschopnost a zaměstnanost - výzvy a cesty vpřed do 21. století. (1994). Praha: Ústav mezinárodních vztahů.

Bosman, C., Gérard, F., \& Roegiers, X. (2000). Quel avenir pour les compétences? Bruxelles: De Boeck Université.

Boutin, G., \& Julien, L. (2000). L'obsession des compétences. Son impact sur l'école et la formativ des enseignants. Montréal: Editions Nouvelles.

Crahay, M. (2006). Dangers, incertitudes et incomplétude de la logique de la compétence en éducation. Revue française de pédagogie, 154(1), 97-110.

Deer, C. (2006). Le Curriculum national en Angleterre: entre logique politico-idéologique et didactico-pédagogique. In F. Audigier, M. Crahay, \& J. Dolz (Eds.), Curriculum, enseignement et pilotage (s. 85-98). Bruxelles: De Boeck.

de Jong, T. (2010). Cognitive load theory, educational research, and instructional design: Some food for thought. Instructional Science, 38(2), 105-134.

European Commission (1995). White paper on education and training. Teaching and learning Towards the learning society. Luxembourg: Office for official publications of the European communities.

European Round Table (1989). Education and European competence in Europe. Brussels: ERT.

Fayol, M. (1991). From sentence production to text production. European Journal of Psychology of Education, 6(2), 101-119.

Glaser, R. (1984). Education and thinking: The role of knowledge. American Psychologist, 39(2), 93-104.

Goodson, I. F. (2008). Curriculum reform and curriculum theory: A case of historical amnesia. In N. Norris (Ed.), Curriculum and the teacher. 35 years of the Cambridge Journal of Education (s. 131-141). London: Routledge.

Harlé, I. (2010). La fabrique des savoirs scolaires. Paris: La Dispute.

Hirtt,N.(2009).L'approche parcompétences: unemystification pédagogique. L'école démocratique, 39(septembre). Dostupné z http://www.skolo.org/spip.php?article1099\&lang=fr.

Chi, M. T. H., Feltovich, P., \& Glaser, R. (1981). Categorization and representation of physics problems by experts and novices. Cognitive Science, 5(2), 121-152.

Chi, M. T. H., Glaser, R., \& Farr, M. J. (Eds.). (1988). The nature of expertise. Hillsdale, NJ: Erlbaum. Kaščák, O., \& Pupala, B. (2011). PISA v kritickej perspektíve. Orbis Scholae, 5(1), 53-70.

Kaščák, O., \& Pupala, B. (2012). Škola zlatých golierov. Vzdelávanie v ére neoliberalismu. Praha: SLON. 
Lannoye, C. et al. (1999). L'école vit... au rythme de ses tensions. Bruxelles: De Boeck Education.

Martinand, J.-L. (2003). La question de la référence en didactique du curriculum. Investigações em Ensino de Ciências, 8(2), 125-130.

Minsky, M. (1974). A framework for representing knowledge. Dostupné z http://web.media.mit. edu/ minsky/papers/Frames/frames.html

MŠMT (2008). Školská reforma pokračuje. Vzdělávání v r. 2008 v tématech. Praha: Ústav pro informace ve vzdělávání.

OECD (2001). Quel avenir pour nos écoles? Paris: OECD Publishing.

Parlement européen (2006). Les compétences clés pour l'éducation et la formation tout au long de la vie. Luxembourg: Office des publications officielles des Communautés européennes.

Recht, D. R., \& Leslie, L. (1988). Effect of prior knowledge on good and poor readers' memory of text. Journal of Educational Psychology, 80(1), 16-20.

Rendl, M., \& Štech, S. (2012). Should learning (mathematics) at school aim at knowledge or at competences? Orbis Scholae, 6(2), 23-40.

Resnick, L. B., \& Ford, W. W. (1981). The psychology of mathematics for instruction. Hillsdale: LEA.

Rey, B. (1996). Les compétences transversales en question. Paris: ES.

Rey, O. (2008). From the transmission of knowledge to a competence-based approach. Dossier d'Actualité, 34(april). Dostupné z http://www.academia.edu/706747/From_the_ transmission_of_knowledge_to_a_competence-based_approach

Rey, O. (2010). Contenus et programmes scolaires: comment lire les réformes curriculaires? Dossier d'Actualité, 53(avril). Dostupné z http://www.inrp.fr/vst/LettreVST/53-avril2010.php.

Rey, B., Carette, V., \& Kahn, S. (2002). Lignes directrices pour la construction d'outils d'évaluation relatifs aux socles de compétences. Rapport auprès de la Commission des outils d'évaluation. Bruxelles: Commission de pilotage.

Rychen D. S., \& Salganik, L. H. (Eds.). (2001). Defining and selecting key competencies. Göttingen: Hogrefe \& Huber Publishers.

Schneider-Gilot, M. (2006). Quand le courant pédagogique „des „compétences“ empêche une structuration des enseignements autour de l'étude et de la classification de questions parentes. Revue Française de Pédagogie, 154(janvier-février-mars), 85-96. Dostupné z http://rfp.revues.org/136

Sternberg, R. J. (1985). All's well that ends well, but it's a sad tale that begins at the end: A reply to Glaser. American Psychologist, 40(5), 571-573.

Straková, J. (2010). Postoje českých učitelů k hlavním prioritám vzdělávací politiky. In R. Váňová \& H. Krykorková (Eds.), Učitel v současné škole (s. 167-175). Praha: FF UK.

Straková, J. (2013). Jak dál s kurikulární reformou. Pedagogická orientace, 23(5), 735-744.

Sweller, J. (1988). Cognitive load during problem solving: Effects on learning. Cognitive Science, 12(2), 257-285.

Sweller, J. (1994). Cognitive load theory, learning difficulty, and instructional design. Learning and Instruction, 4(4), 295-312.

Sweller, J. (2005). The redundancy principle in multimedia learning. In R. E. Mayer (Ed.), Cambridge handbook of multimedia learning (s. 159-167). Cambridge, UK: Cambridge University Press. 
Sweller, J., Mawer, R. F., \& Ward, M. R. (1983). Development of expertise in mathematical problem solving. Journal of Experimental Psychology: General, 112(4), 639-661.

Štech, S. (2009). Zřetel k učivu a problém dvou modelů kurikula. Pedagogika, 59(2), 105-115.

Tardif, J. (1999). Le transfert des apprentissages. Montréal: Éd. Logiques.

Thorndike, E. L. (1922). The psychology of arithmetic. New York: The MacMillan Company.

Tilmant, F. (2005). Les compétences: concepts et enjeux. Cahiers des Sciences de l'Education, 21-22, Service de pédagogie expérimentale, ULg.

Young, M. (2007). Bringing knowledge back in: From social constructivism to social realism in the sociology of education. London: Routledge.

Young, M. (2010). Alternative educational futures for a knowledge society. European Educational Research Journal, 9(1), 1-12.

\section{Autor}

prof. PhDr. Stanislav Štech, CSc., Univerzita Karlova, Pedagogická fakulta, Katedra psychologie, M. D. Rettigové 4, 11639 Praha 1; e-mail: stanislav.stech@pedf.cuni.cz

\section{On an evidence-less curricular reform}

Abstract: The topic of the study consists in the analysis of the "story“ of the Czech curricular reform based on the comparison of its concepts and logic with the results of educational and psychological research in teaching and learning. The first part attempts to prove that the failure of the reform mostly rejected by teachers doesn't consist in the lack of communication with them. The following part reveals the old tension between thinking/student oriented vs. subject oriented teaching behind current reform clichés. As the core and the symbol of the curricular reform, the notion of competence is critically analyzed: it is a bad answer, because it is not research evidence-based, to a good question. The last part deals with three issues from psychological research the results of which the reform largely ignored: (1) predominant focus on problem solving ignoring the results of research on the relationship between working memory and long-term memory and in the cognitiveload theory, (2) stress on the transversal competences as the goal of teaching ignoring the narrow and strong link of the thinking skills with the specific object of thinking and its epistemological constraints, and (3) challenging the belief the (far) transfer could play the role of the criterion of the learning effectiveness. Thus, the curricular reform was more ideology-driven than evidence-based.

Keywords: curriculum, educational reform, competence, learning, transfer 